\title{
Environment \& Health: perspectives and challenges
}

\section{Saúde \& Ambiente: perspectivas e desafios}

Ronaldo Figueiróo ${ }^{1,2}$

Adriano Arnóbio ${ }^{3}$

\begin{abstract}
The concept of health and environmental health is a historical-conceptual relation with the twentieth century. In this article, environmental health is discussed as a of intersectional and transdisciplinary practices dedicated to the reflections, in human health, of the ecogeossocial relations of man with the environment, aiming well-being, life quality and sustainability, in order to guide public policies formulated using the available knowledge and with social participation and control. In this context, infectious diseases play a key role in the comprehension of environmental health in Brazil and worldwide.
\end{abstract}

Keywords: Health, environment, environmental health, ecology, infectious diseases.

\section{Resumo}

O conceito de saúde e saúde ambiental é uma relação histórica-conceitual com o século XX. Neste artigo a Saúde ambiental é discutida como um campo de práticas intersetoriais e transdisciplinares voltadas aos reflexos, na saúde humana, das relaçóes ecogeosociais do homem com o ambiente, com vistas ao bem-estar, à qualidade de vida e à sustentabilidade, a fim de orientar políticas públicas formuladas com utilização do conhecimento disponível e com participação e controle social.Neste contexto, as doenças infecciosas têm um papel fundamental na compreensão da saúde ambiental no Brasil e no mundo.

Pavavras-chave: Saúde, meio ambiente, saúde ambiental, ecologia, doenças infecciosas. 


\section{INTRODUCTION}

The United Nations Conference on the Human Environment, held in 1972 was the turning point to a worldwide concern about environmental issues and state intervention, which led to a new level of international networking. In this process, the debate on the issue of poverty is contrasted to the use of natural resources. (Brasil, 2002)

The United Nations Conference on Environment and Development held in Rio de Janeiro in 1992 consolidated principles already pointed out in 1972 . These principles, among others, have been consolidated through the "Rio Declaration on Environment and Development" (Brasil, 2007).

Three principles can be deployed to a better understanding of the relation between health and environment: The first principle - "Human beings are at the centre of concerns for sustainable development. They are entitled to a healthy and productive life in harmony with nature". This principle states that humans are the center of concerns - which presents human health as a center for joint development and environment. (United Nations, 1992)

Two other principles that assist in the understanding of health and environment, the eighth principle - "To achieve sustainable development and a higher quality of life for all people, States should reduce and eliminate unsustainable patterns of production and consumption and promote appropriate demographic policies.", a principle that seeks to incorporate the concept of quality of life to promote a healthy environment. What nowadays is in charge of Health Promotion. The fourth principle - "In order to achieve sustainable development, environmental protection shall constitute an integral part of the development process and cannot be considered in isolation from it". This principle is intended to integrate the development stage of sustainable development, providing environmental protection as an integral and inseparable part of this process.(United Nations, 1992)

From the perspective of these international principles the framework of discussions on environment, health and development was built.

\section{CONCEPTS - HEALTH AND ENVIRONMEN- TAL HEALTH}

Concerns about environmental issues are inserted in the Public Health since its inception. In human history the major health challenges are related to the community, infectious diseases, improving sanitation and access to water and food consumption conditions. The emphasis on solving each challenge regarding human health varies over time and history, although only in the second half of the twentieth century a specific area to address these issues was structured. (Rosen, 1958)

In the mid-twentieth century there was a concern of the WHO in conceptualizing health. The World Health Organization (WHO) defined health as a complete state of physical well-being, mental and social and not merely the absence of disease (WHO, 1946).

In Brazil, the concept of environmental health was defined in the manual "Subsidies for the Construction of the Environmental Health National Policy", aiming to develop the national policy of environmental health.(Brasil,2007)

The study Field of Environmental Health comprises the area of Public Health, related to the scientific knowledge and to the formulation of public policies and to its corresponding interventions, related to the interaction between human health and the natural and antropic environmental factors that determine and influence them, in order to improve life quality of human beings under the perspective of sustentability. (Gouveia,1999)

It is a field of intersectorial and transdisciplinary practices, dedicated to reflexes, in human health, of the ecogeossocial relations of man with the environment, aiming well being, life quality and sustentability, in order to orientate public policies formulated using the available knowledge and with social participation and control.(Periago,2007)

In this context, infectious diseases have a key role in the understanding of environmental health in Brazil and worldwide.(Rattner,2009)

\section{ENVIRONMENTAL HEALTH AND INFEC- TIOUS DISEASES.}

The relationship between the environment humans live in and infectious diseases is a long discussed topic in literature, however, only recently a more ecological approach to infectious diseases became more common in scientific studies (Conrad,2005). Infectious diseases can be defined as the overlapping in time and space of the ecological niches of the populations involved in the disease: hosts, pathogens, vectors and reservoirs.

The concept of ecological niche was originally proposed by Grinnel (1917) as the role a given species play in its environment, which is basically defined by the biotic and abiotic resources it uses. Hutchinson (1957) has expanded this original concept adding the notion of multiple niche dimensions: space, food, seasonality, etc.

The environment is constantly changing, and all living organisms must evolve in order to adapt to these continuously changing conditions (Van Valen 1973). That is, as the environment is changing, so are the available niches, 
and thus, organisms must follow these changes shifting their potential niches or perishing.

This neverending race proposed in the Red Queen Hypothesis has strong implications on infectious disease dynamics, as mankind had major impact in the environment, and over the centuries basically human populations have undergone several behavioral and structural changes. Basically, these human transitions had reflections in their pathogens: when humans shifted their main foraging strategy from hunting to agriculture, this allowed larger populations and led to animal domestication, which resulted in the rise of the first zoonotic infections (Wolfe et al. 2007).

Another great shift in the structure of human populations came with the industrial revolution, when life expectancy was lengthened by the decrease in infectious disease and infant mortality, while on the other hand, noninfectious chronic diseases arose (Montira et al. 2009).

While the notion of the intimate link between environment and infectious diseases has been well established over the years, most of the studies that deal with disease dynamics often approach these systems in a simplistic manner: as three (pathogen, vector, host) or four (when a reservoir is also involved) compartments model (Figueiró \& Gil-Azevedo, 2010). This can be an useful approach for short term predictions and interventions, as noted by Ellis \& Wilcox (2009), however, this typical epidemiological simplified model which ignores the interactions between the the populations directly involved in a given disease dynamics and the rest of the biological communities they belong to has limited application for longer term predictions.

The concept of population regulation is one of the pillars of population ecology, which echoes directly in community ecology: all populations of living organisms have their growth limited by resources and interactions with other organisms, which can be intraspecific or interspecific. This phenomenon has important implications when it comes to infectious disease dynamics: vectors, reservoirs and pathogens may be regulated by resources and other populations which generally are not accounted for in the traditional approach used in most studies.

As the transmission of infectious diseases is basically an ecological process, species diversity and community structure can influence the prevalence of infectious diseases (Keesing et al. 2006). There is a well established pattern in literature that more diversity reduces disease risk in biological communities: Elton (1958), in his influential book "The ecology of invasion by animals and plants", suggested that plant diseases could be attenuated in complex ecosystems, an hypothesis that was corroborated in empirical studies (Boudreau \& Mundt 1997) and epidemiological models (Anderson \& May 1981).
This intimate relationship between biodiversity and disease risk is alarming, as recently the Millennium Ecosystem Assessment, which was an ensemble of over 1000 of the world's leading biological researchers, analyzed the current state of the world's main ecosystems, releasing an astounding report of the profound degradation and biodiversity loss in all of the studied ecosystems (Millennium Ecosystem Assessment 2005).

Over the last decades, deforestation and habitat loss have strongly contributed to the decline in biological diversity (Pimm \& Raven 2000). The first organisms that disappear with habitat fragmentation are often the predators from the top of the trophic web, what strongly compromises the top-down regulation in these communities.

Another relevant issue that compromises the ecosystem stability is the constantly growing number of biological invasions, partly due to the improvement in human transportation means, that can have a direct or indirect effect in disease dynamics. As defined earlier, the dynamics of an infectious disease can be described as the overlapping in time and space of the ecological niches of the organisms involved, thus, biological invasions may represent niche overlap of organisms that never would have had contact with each other in natural conditions (which may be, for instance, the introduction of a potential vector or pathogen where it was the only link absent for the occurrence of a given disease).

An example of species introductions causing the emergence of diseases where they didn 't exist previously is the introduction of the Aedes aegypti, vector of the Yellow Fever and Dengue, which is originally from Africa and was introduced in the Americas as a consequence of the slave market (Consoli \& Lourenço-de-Oliveira 1994).

Another potential impact exotic species introduction may have in biological communities is promoting a shape shift in the effective niches of the native species, what may indirectly affect one of the populations involved in a given disease (for instance, the exotic species may negatively affect one of the species that regulate the pathogen, reservoir or vector, hence improving the effective niche of the mentioned species, and consequently increasing its niche overlap with the other organisms involved in the disease).

In order to any disease to persist in a given ecosystem, a minimal amount of succetible hosts must be available, what is known in literature as the transmission threshold. This transmission threshold may be improved in very diverse communities by what is known as the amplification effect: the occurrence of several alternative hosts with similar host competences lower the transmission thresholds for each of the host populations (Keesing et al. 2006).

However, species diversity may also affect disease dynamics through what is known as the dilution effect (Nor- 
man et al. 1999): a large number of alternate hosts with varied host competences may decrease the disease incidence in the focal host, hence decreasing the disease impact in the community as the pathogens will dilute through the nonoptimal hosts.

It is clear that ecosystem health is directly related to human health. The biological complexity of communities often translates into regulation mechanisms that limit somehow disease severity. However, it is common to approa$\mathrm{ch}$, in an anthropocentric view, how ecosystems affect disease, but rarely the opposite is given the deserved attention: how does disease affect the ecosystems?

Habitat loss and climate change are often viewed as the major factors involved in biodiversity loss, however, the introduction of pathogens associated with human activities in ecosystems where they were previously absent is also an important source of disturbance in biological communities.

Paine (1969) proposed the concept of keystone-predator, that is an organism whose population affects disproportionally the rest of the biological community. The removal of such keystone organisms deeply affects the community structure, often resulting in biodiversity loss.

The sea-otters were one of the fist keystone-species described in literature (Estes \& Pamisano 1974), and today these organisms face a threat imposed by human activities: cat feces, thrown through sewage in the sea, are causing an epidemics of Toxoplasmosis among sea-otter populations. The incidence of this disease stagnated the population growth of sea-otters until 1995, and a decline from 1996 to 2002 (Conrad et al 2005), which predictably will have a strong impact in these community structures.

Another keystone-species strongly affected by disease introduction are the prairie dogs, which are keystone-organisms in the grasslands (Miller \& Cully 2001). These natural populations have been impacted by the introduction of Yersinia pestis, the ethiological agent of the sylvatic plague. When populations of black-tailed and Gunningson`s prairie dogs are exposed to the pathogen, it causes nearly $100 \%$ mortallity (Cully 1997, Miller \& Cully 2001).

\section{CONCLUSIONS}

Today it is impossible to dissociate human health from environmental health: there is a reciprocal effect between the two. To address ensuing health and environmental issues, the challenge society faces is to approach those in an integrated way, which is something that demands serious reflections about the anthropocentric nature of human thought.

\section{REFERÊNCIAS BIBLIOGRÁFICAS}

1. Anderson, R. M. and May, R. M. 1981. The population dynamics of microparasites and their invertebrate hosts. Philos. Trans. R. Soc. Lond. B Biol. Sci 291:451-524.

2. Boudreau, M.A. and Mundt, C.C. 1997. Ecological approaches to disease control. In: Environmentally Safe Approaches to Crop Disease Control (ed. Rechcigl, N.A. \& J.E. Rechcigl). CRC Publications, Boca Raton, FL, USA, pp. 33-62.

3. Brasil, Ministério da Saúde, Fundação Nacional de Saúde FUNASA. 2002. Textos de epidemiologia para vigilância ambiental em saúde/coordenado por Volney de M. Câmara. Brasília. 132p.

4. Brasil, Ministério da Saúde, Secretaria de Vigilância em Saúde, Coordenação Geral de Vigilância em Saúde Ambiental. 2004. Relatório Final - Simpósio Internacional sobre a Construção de Indicadores para a Gestão Integrada em Saúde Ambiental. P.30.

5. Brasil. Ministério da Saúde. Conselho Nacional de Saúde. 2007. Subsídios para construção da Política Nacional de Saúde Ambiental / Ministério da Saúde, Conselho Nacional de Saúde. - Brasília: Editora do Ministério da Saúde. P.56.

6. Conrad, P.A., Grigg, M.E, Kreuder, C. et al. 2005. Sea otters serve as sentinels for protozoal pathogens transmitted from the terrestrial hosts to marine mammals (abstract). In Cary Conference 2005: Infectious Disease Ecology 56. Millbrook: Institute for ecosystem studies.

7. Consoli, R.A.G.B. and Lourenço-de-Oliveira, R. 1994.Principais mosquitos de importância sanitária no Brasil. Editora Fundação Instituto Oswaldo Cruz, Rio de Janeiro, Brasil,p. 228 .

8. Cully, J. F., Jr. 1997. Growth and life-history changes in Gunnison's prairie dogs after a plague epizootic. Journal of Mammalogy 78: 146-157.

9. Ellis, B.R. and Wilcox, B.A. 2009. The ecological dimensions of vector-borne disease research and control. Cadernos de Saúde Pública 25: S155-S167.

10. Elton, C.S. 1958. The Ecology of Invasions by Animals and Plants. Methuen \& Co., London. P. 196. 
11. Estes, J.A. and Pamisano, J.F. 1974. Sea Otters: Their Role in Structuring Nearshore Communities, Science 185: 1058-1060.

12. Figueiró, R and Gil-Azevedo L.H. 2010. The role of neotropical blackflies (diptera: simuliidae) as vectors of the onchocerciasis: a short overview of the ecology behind the disease. Oecologia Australis 14: 745-755.

13. Gouveia, N. 1999. Saúde e meio ambiente nas cidades: os desafios da saúde Ambiental. Saúde e Sociedade 8: 49-61

14. Grinnell, J. 1917. The niche-relationships of the California Thrasher. The Auk 34: 427-433.

15. Hutchinson, G.E. (1957) Concluding remarks- Cold Spring Harbor Symposia on Quantitative Biology.22:415-427. Reprinted in 1991: Classics in Theoretical Biology. Bull. Math. Biol. 53: 193-213.

16. Keesing, F., Holtz, R.D., Ostfeld, R.S. 2006. Effects of species diversity on disease risk. Ecological Letters 9:485-498.

17. Millennium Ecosystem Assessment, 2005. Ecosystems and Human Well-being: Biodiversity Synthesis. World Resources Institute, Washington, DC.p.100.

18. Miller, S.D., and Cully, J. F., Jr. 2001. Conservation of black-tailed prairie dogs (Cynomys ludovicianus). Journal of Mammalogy 82: 889-893.

19. Norman, R., Bowers, G., Begon, M. et al .1999. Persistence of tick-borne virus in the presence of multiple host species: Tick reservoirs and parasite-mediated competition. Journal of Theoretical Biology 200:111-118

20. Paine, R.T. 1969. A note on trophic complexity and species diversity. American Naturalist 100:91-93.
21. Periago, M. R., Galvão, L. A., Corvalán,C. et al . 2007. Saúde Ambiental na América Latina e no Caribe: numa encruzilhada. Saúde e Sociedade 16: 14-19

22. Pimm, S.L. and Raven, P. 2000. Extinction by numbers. Nature 403: 843-845.

23. Montira, J., Pongsiri, J.R., Ezenwa, V.O. et al . 2009. Biodiversity Loss Affects Global Disease Ecology. Biosciences 59:945-954.

24. Van Valen, L. 1973. A new evolutionary law. Evolutionary Theory 1:1-30.

25. Wolfe, N.D., Dunavan, C.P., Diamond, J. 2007. Origins of major human infectious diseases. Nature 447: 279-283.

26. Rattner, H. 2009. Meio ambiente, saúde e desenvolvimento sustentável. Ciência \& Saúde Coletiva 14:19651971.

27. Ribeiro, H. 2004. Saúde Pública e Meio Ambiente: evolução do conhecimento e da prática, alguns aspectos éticos. Saúde e Sociedade 13:70-80.

28. ROSEN, G. 1958. A history of public health. New York: MD Publications,. 551p.

29. Scliar, M. História do Conceito de Saúde. 2007.

30. PHYSIS: Rev. Saúde Coletiva 17:29-41.

31. Sobral, A., Freitas, C. M. 2010. Modelo de Organização de Indicadores para Operacionalização dos Determinantes Socioambientais da Saúde. Saúde e Sociedade 19: 35-47.

32. United Nations 1992. Rio Declaration on Environment and Development. The United Nations Conference on Environment and Development, Rio de Janeiro, Brasil, 3-14 Jun. 